\title{
THE IN VITRO EVALUTION OF CYMBOPOGEN \\ CITRATUS (LEMONGRASS) ESSENTIAL OIL AS \\ POTENTIAL ANTIMICROBIAL AGENT IN POULOTRY \\ PRODUCTS
}

\author{
El-Nawawy, M. ${ }^{(1)}$; Ragab, M. $^{(1)}$ and El-Adawy, B. A. ${ }^{(2)}$ \\ 1) Institute of Environmental Studies and Research, Ain Shams University \\ 2) United States Naval Medical Research
}

\begin{abstract}
This study was carried out to investigate the potential of using essential oil extract of Lemongrass (Cymbopogon citratus) as natural antibacterial agent at three different concentrations $\left(100,200\right.$ and $\left.500 \times 10^{3} \mathrm{ppm}\right)$ against 60 human isolates from diarrheal and septicemic cases in addition to 7 ATCC (American Type of Culture Collection) strains belonging to 3 different species of Gram negative bacteria including Salmonella spp, Shigella spp and Campylobacter spp and one Gram positive bacteria which is Staph. aureus. The screening was performed by standard disc diffusion method.

Essential oil extract of lemongrass exhibited maximum activity against C. jejuni with $30.62 \mathrm{~mm}$, Staph. aureus with $11.91 \mathrm{~mm}$, Shigella spp with $11.73 \mathrm{~mm}$ and Salmonella spp with $9.41 \mathrm{~mm}$ mean diameter of zone of inhibition at the lowest used concentration, $100 \times 10^{3} \mathrm{ppm}$ of the essential oil.

Accordingly, lemongrass essential oil extract was found to be effectively inhibiting both gram-positive and gram-negative bacteria and can be a good source of antibacterial agents for possible infections in poultry products.

Key words: Lemongrass, antibacterial agents, Salmonella, Shigella, Campylobacter.
\end{abstract}


J. Environ. Sci.

Institute of Environmental Studies and Research - Ain Shams University

\section{INTRODUCTION}

Poultry provide humans with companionship, food and fiber in the form of eggs, meat and feathers. Globally, production of the primary poultry products has been raising rapidly this reflects consumption based, in turn, on consumer preference for these high-quality products and the relatively low price because of efficiency of production. Over a 10-year period between 1995 and 2005, consumption, and hence production, has increased globally for chicken meat (53\%), turkey meat (13\%), duck meat (67\%), goose meat (53\%), chicken eggs (39\%), and other eggs (27\%) (Scanes 2007). Meanwhile, bacterial foodborne illness affects 48 million people in United States with 128,000 hospitalizations and 3,000 deaths (CDC, 2011). In addition to affecting millions each year, bacterial foodborne diseases are very expensive causing huge losses to the food industry and consumers. Despite methods to reduce or eliminate bacterial foodborne pathogens, food poisoning is still a major concern (Shan et al., 2007). Due to increasing awareness among consumers and the increasing demand for "organic" foods free of synthetic additives and preservatives, the interest in developing novel antibacterial substances has increased (Suhaj, 2006).

The aim of this study is to use natural extract and compounds environmentally and healthy safe in the poultry slaughterhouses and industries to control some of microbial diseases that commonly occur in poultry which are Salmonella, Shigella, Staphylococcus aureus and Campylobacter isolates. Objectively, this study is to contribute information that will help to mitigate the microbial pollutants in poultry. 


\section{MATERIAL AND METHODS}

Bacterial strains: Sixty human blood and stool isolates of Campylobacter spp, Shigella spp, Salmonella spp and Staphylococcus aureus. In addition to seven reference strains of Salmonella typhi, Shigella flexneri, Campylobacter jejuni, Campylobacter coli and Staphylococcus were obtained from NAMRU3 laboratory. Namely; S. typhi ATCC19430, Staph. aureus ATCC 25923, Staph. aureus (MRSA) ATCC 43300, Campylobacter jejuni ATCC 33291, Campylobacter jejuni (Invasive) ATCC 81176, Campylobacter coli ATCC 33559 and Sh. flexneri ATCC12022. All isolates and reference strains were stored at $-80^{\circ} \mathrm{C}$ in brain heart infusion broth containing $15 \%$ glycerol (PrattRippin and Pezzlo, 1992) since isolated as well as the reference strains were used for testing the quality of prepared media, reagents and spices oil extract discs used in this study. All bacterial isolates were recovered from preserved cryo-vials stored at $-80^{\circ} \mathrm{C}$ using MacConkey plates that were incubated for 24 hours at $35 \pm 1^{\circ} \mathrm{C}$ and Blood plates that were incubated for 24 hours at $35 \pm 1^{\circ} \mathrm{C}$ with 5\% Carbon Dioxide while the Skirrow plates that were incubated for 48 hours at $42^{\circ} \mathrm{C}$ in candle jars to maintain the microaerophilic atmosphere.

Lemongrass essential oil: Extract of Cymbopogon citratus (lemongrass) essential oil was gotten ready from Kanater station for essential oil production Agric. Res. Center, Egypt.

Antimicrobial activity screening: The antibacterial activity of essential oil extract was determined by the disc diffusion method as described by Clinical and Laboratory Standards Institute (CLSI) using the disc diffusion method by sterilized discs of filter paper which impregnated with $50 \mu \mathrm{L}$ of essential oil extract dilutions of lemongrass before being placed on the 
Mueller Hinton agar plates (100x15 mm) which inoculated with standardized inoculum $\left(1.5 \times 10^{8} \mathrm{CFU} / \mathrm{mL} ; 0.5 \mathrm{McFarland}\right)$ of each freshly cultured of testing isolates and reference strains (Salmonella spp, Shigella spp, Staphylococcus aureus) suspended in sterile normal saline solution $(0.85 \%)$ that was spread with the help of sterile cotton applicator. For Campylobacter spp, large plates of Mueller Hinton agar with blood were inoculated with standardized inoculum $\left(3 \times 10^{8} \mathrm{CFU} / \mathrm{mL} ; 1\right.$ McFarland $)$ of each Campylobacter spp. using sterile cotton applicator. In addition to, negative control check embodied in sterile filter paper discs moistened with $50 \mu \mathrm{L}$ of each or combination of Tween-80 and Aqueous Dimethyl Sulfoxide (DMSO) at different concentrations. All inoculated plates of Salmonella, Shigella and Staphylococcus aureus containing the impregnated discs were incubated in an upright position at $35 \pm 1{ }^{\circ} \mathrm{C}$ overnight and the inoculated plates of Campylobacter spp. containing the impregnated discs were incubated in an upright position in candle jar at $42^{\circ} \mathrm{C}$ for 48 hours. After incubation inhibition zone diameters were measured using digital caliper.

\section{RESULTS AND DISCUSSION}

Salmonella spp, Shigella spp, Campylobacter spp and Staph. aureus were chosen as models for Gram-negative and Gram-positive bacteria because they are widespread serious foodborne pathogens in all food industry sectors and they pose increasing risks as by public health overseers (Archer, 1998; Bell and Kyriakides, 2002; Blackburn and McClure, 2002). The usage of antimicrobial resistant strains was suggested in our study because this provides more reliability and validity about the efficiency of examined 
antimicrobial agents. These reference strains are invasive Campylobacter jejuni and Methicillin Resistant Staphylococcus aureus (MRSA). Both have shown reasonable results by giving a zone of inhibition 11.90 and $10.80 \mathrm{~mm}$ respectively, which can naturally control this kind of difficult organisms in poultry products.

Also, as shown in Table 1, the zone of inhibition for all types of bacteria significantly decreased with the increase of the essential oil concentration as a maximum activity against $C$. jejuni with $30.62 \mathrm{~mm}, \mathrm{~S}$. aureus with $11.91 \mathrm{~mm}$, Shigella spp with $11.73 \mathrm{~mm}$ and Salmonella spp with $9.41 \mathrm{~mm}$ mean diameter of zone of inhibition at $100 \times 10^{3} \mathrm{ppm}$ concentration of the essential oil. These inhibition zones have increased dramatically by increasing the essential oil concentration.

Table 1: Effect of different concentrations of Lemon -grass essential oil on different types of bacteria (mean diameter of zone of inhibition in $\mathrm{mm})$.

\begin{tabular}{|c|c|c|c|c|c|}
\hline $\begin{array}{c}\text { Conce- } \\
\text { ntration } \\
\text { (ppm) }\end{array}$ & $\begin{array}{c}\text { Campylobacter } \\
\text { spp }\end{array}$ & $\begin{array}{c}\text { Campylobacter } \\
\text { jejuni* }\end{array}$ & $\begin{array}{c}\text { Shigella } \\
\text { spp }\end{array}$ & $\begin{array}{c}\text { Salmonella } \\
\text { spp }\end{array}$ & $\begin{array}{c}\text { Staph. } \\
\text { aureus }\end{array}$ \\
\hline $500 \times 10^{3}$ & 96.81 & 29.80 & 21.76 & 12.73 & 41.81 \\
\hline $200 \times 10^{3}$ & 51.21 & 15.70 & 16.87 & 10.06 & 31.82 \\
\hline $100 \times 10^{3}$ & 30.62 & 11.90 & 11.73 & 9.41 & 11.91 \\
\hline
\end{tabular}

Invasive ATCC strain of Campylobacter jejuni

Pathogen control and decontamination measures significantly increase production costs. Moreover, contamination of food products with bacterial pathogens can seriously reduce consumer demand and affect producer profits (Pohlman et al., 2002). The bio-preservative agent introduced in this study 
was extracted from byproduct and inexpensive plant material which have economic importance for both producers and consumers.

In conclusion, since food safety is a major concern to the food industry and the consumers, research is ongoing constantly to find more effective methods to reduce or kill foodborne bacterial pathogens. In this study it was shown that the essential oil of lemongrass was effective in mitigate Campylobacter jejuni, Shigella spp, Salmonella spp and Staphylococcus aureus strains.

\section{REFERENCES}

Archer, G.L. (1998): Staphylococcus aureus: A well-armed pathogen. Clin. Infect. Dis., 26, 1179-1181.

Bell, C.; and Kyriakides, A. (2002): Salmonella: A Practical Approach to the Organism and Its Control in Foods. Oxford: Blackwell Publishing Ltd.

Blackburn, W.; and McClure, P.J. (2002): Foodborne Pathogens: Hazards, Risk Analysis, and Control. Cambridge: Woodhead Publishing Ltd.

Centers for Disease Control and Prevention (CDC, 2011). Division of Foodborne, Waterborne and Environmental Diseases (DFWED) (accessed on 17 August 2016). Available online: http://www.cdc.gov/foodborneburden/2011-foodborneestimates.html

Pohlman, F.W.; Stivarius, M.R.; McElyea, K.S., and Waldroup, A.L. (2002): Re-duction of E. coli, Salmonella typhimurium, coliforms, aerobic bacteria, and improvement of ground beef color using trisodium phosphate or cetylpyridinium chloride before grinding. Meat Sci., 60, 49-356. 
Pratt-Rippin and Pezzlo. (1992): In Isenberg, Clinical microbiology procedures handbook vol. 1. American Society for Microbiology, Washington, D.C.

Scanes, C.G. (2007): The Global Importance of Poultry. Poultry Science, 86 (6), 1057-1058.

Shan, B.; Cai, Y.Z.; Brooks, J.D., and Corke, H. (2007): The in vitro antibacterial activity of dietary spice and medicinal herb extracts. Int J. Food Microbial., 117, 112-119.

Suhaj, M. (2006): Spice antioxidants isolation and their antiradical activity: A review. J. Food Compos. Anal., 19, 531-537.

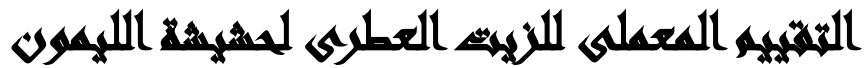

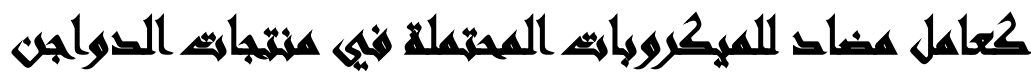

\section{$[\vee]$}

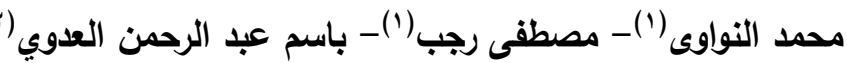

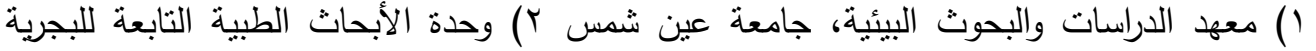
الأمريكية

\section{المستطلي}

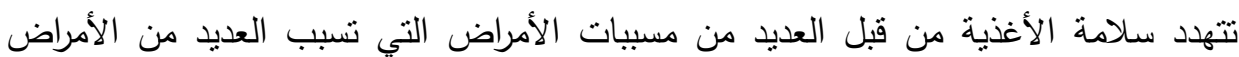

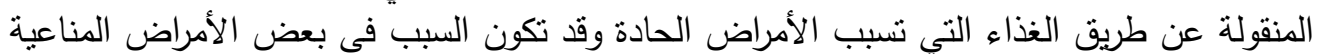

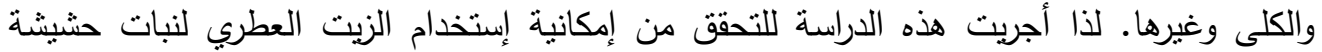

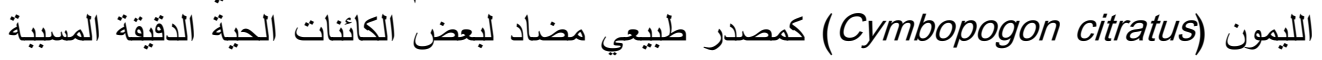

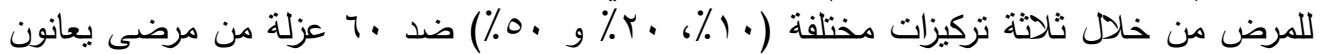

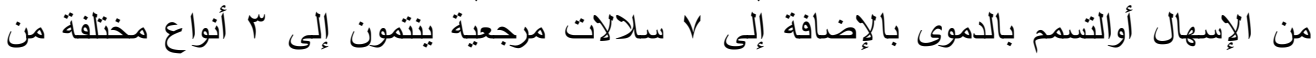

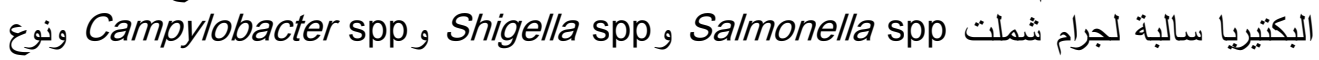
آخر موجب لصبغة الجرام وهو Staph. aureus. تم إجراء الفحص بإستخدام طريقة الانتشار

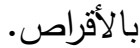


J. Environ. Sci.

Institute of Environmental Studies and Research - Ain Shams University

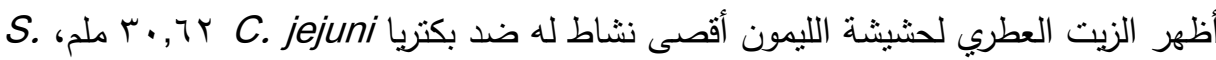
(1,9 1, aureus قطر منطقة التثبط عند أقل تركيز مستخدم 100x103 جزء في في المليون من الزيت العطري.

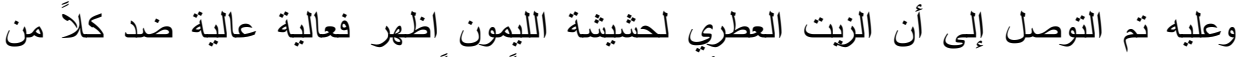

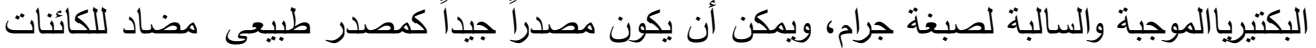
الحية الدقيقة يمكن استخدامه فى حفظ بعض المنتجات الغذائية خاصة منتجات لحوم الدواجن. 